\title{
Design of logistic processes by the Factor-Indicator-Model
}

\author{
Prof. F. J. Heeg, T. Gühring \\ BIBA (Bremen Institute of Industrial Technology and \\ Applied Work Science) \\ D-28359 Bremen, Hochschulring 20, Germany \\ Phone: +49(0)421/218-02, Fax: +49(0)421/218-5510 \\ e-mail:zsek@biba.uni-bremen.de
}

\begin{abstract}
The Factor-Indicator-Model intends to give reference for the design of business processes in order to specify, facilitate and stabilise improvement activities in complex business environments. The paper monitors the system approach, elements of the model, supporting methods and steps in application based on examples of a benchmarking project.
\end{abstract}

\section{Keywords \\ Process modelling, Business process reengineering}

\section{INTEGRATION OF „SUCCESS FACTORS“}

With increasing complexity and dynamic changes in the business environment challenges such as cost leadership or product leadership must be transferred into a company in increasingly less time. Conventional methods considering processes and indicators evaluating the output of a process do not systematically investigate the influences on the process responsible for the performance. By considering success factors in all phases of a reengineering project, most probably changing from hard (technical) success factors to soft success factors in later phases of a reengineering project, success factors are key figures, which necessary improve- 
ment activities are based on. This prioritisation of activities derived from success factors leads to the concentration on most efficient improvement efforts.

\section{APPROACH FOR THE FACTOR-INDICATOR-MODEL}

\subsection{Objective of the approach}

Core idea of the Success-Factor-Performance-Indicator-Model (FI-Model) is to support reengineering projects in dynamic business environments. By focusing on influencing factors and defining success factors, optimisation potentials for better allocation of resources are defined, facilitated and guided through daily work. Improvement under the means of success factors includes hard (technical) as well as soft (human centred) factors. Area of application of the model is the redesign of business processes applied for the optimisation of logistic processes.

\subsection{System theory as theoretical basis}

When conducting reengineering projects it is helpful to structure and visualise the interdependencies of the contents of the project. This allows participants to allocate their knowledge precisely about the case. Such efforts, often not performed systematically, avoid misunderstandings and additional efforts. The approach, applied by BIBA in reengineering projects for optimisation of logistic processes in automotive industry, is to differentiate between processes, influences on the process and performance measurements. Suitable support for this approach is to use the system theory, which basically allows to define equivalent elements: Activities, influencing factors on activities and the indicators for performance. The system model is shown in Figure 1.

These elements as smallest relevant entity in the system as a business unit are exchanging information, material and energy (Ulrich 1970, p. 107) as carried out in a real case. The application of this approach ensures a clear view on the project components. The temporary view on elements and relations between the elements at a certain time provides a network visualising the cause-and-effect-relations between the elements (Eiff 1991, p. 138 ff.). By the system approach a quantitative visualisation of complex but real situations is possible and gives the holistic view on a situation: Ideal for analysing real networks (Schuderer 1997, p. 40).

System theory is providing an important framework defining a certain view on the reengineering project, but it is not necessarily providing solutions. On this analytical level it is hard for employees to understand the meaning of the system model (Staehle 1989, p. 43 f). Therefore, for the application of such a system approach there is the need to develop a method, that is easily assessable and understandable for all involved (Horvàth 1991, p. 7). 


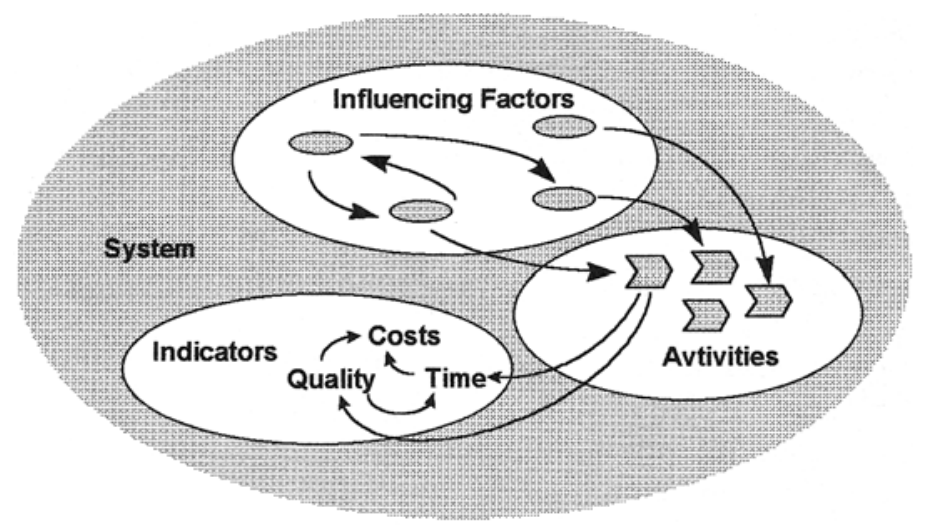

Figure 1 System model for the factor-indicator model

\subsection{Cause-and-effect chain}

A major topic of the proposed model is the cause-and-effect chain of the success factor, the process and its resources and the performance indicator. By separating these elements in the system as a company or a business unit and reducing it to the relevant elements, the FI-model provides transparency by showing the impact of success factors on the process and the underlying resources evaluated by one or view performance indicators. Now an identified gap in performance may be interpreted when analysing the indicator, the process and success factors.

\subsection{Control system}

Taking the business unit or in detail the process between success factor and performance indicator, the model sets up a framework which controls the execution of the business function a process carries out. Using the indicator on one side of the process and the success factor on the influencing side of the process, a control system is defined (Hopfenbeck 1997, p. 58).

\section{SPECIFICATION OF BASIC ELEMENTS}

\subsection{Success factors}

Success factors are major influences on business units or processes determining the performance (DREHER 1997, p. 71). Selected out of many influencing factors, only success factors need to be quantified in order to give necessary information. The intention is not to spend too much time on measurement but on improvement and operation. For categorising the success factors there is a time based difference in operational success factors for short term improvement or long term success 
factors tackling strategic objectives as outsourcing or reconstructing entire departments or parts of the plant. Besides time the second dimension categorising success factors is the differentiation of technical success factors easily to be quantified and "soft" success factors difficult to be quantified and usually „optimised“ by accompanying activities of educational means.

\subsection{Business processes}

Based on an enterprise framework (Bradley, Jordan 1996, p. 4), which classifies an enterprise by enterprise level, business process level and function level, primary and secondary business processes are defined, which fulfil business functions. The functions carried out in the investigated business units may be decomposed from the corresponding main process into sub processes and activities (Lamla 1995, p. 97). Resources are counted in the business unit and allocated to the process(es), sub processes or activities if required regarding the detail of investigation.

\subsection{Performance indicators}

Performance indicators as monetary and non-monetary measures or ratios indicate the performance of the process. Derived form business objectives, one or very few performance indicators are selected, which must be understandable to employees. In the FI-model the indicator fulfils a traffic light function: Indicating that performance is above average, acceptable or below average. When comparing the own performance against another period and/or against another process within or outside the company there must be a process volume as reference for cost, quality or time indicators (Gühring et al 1997, p. 284).

\section{METHODS SUPPORTING THE FI-MODEL}

Reference for the idea of using factors and indicators are the „Profit Impact of Market Strategies" studies basically started in 1960 (Hopfenbeck 1997, p. 413). These studies are postulating the idea, that for the enterprises only few factors exist that are basically responsible for the success of a company (Buzzle, Gale 1989).

The IsHIKAWA diagram shows cause and effect between influencing factors (Hopfenbeck 1997, p. 237). By the FI-approach the process was added separating the cause and effect and quantifying the effect as an performance indicator.

In order to reduce the complexity of the impacts to only very few success factors, as the key factors for improvement, the model applies the idea of scenario techniques as described in terms of network thinking (Ulrich, Probst 1988, p. 143ff.). This method quantifies the relations within a network and evaluates which ele- 
ments are active, neutral or passive - passive meaning that those are mostly influenced by others - reducing the problem to only some success factors.

Improvement finally needs to be supported by the quantitative information about the process. For evaluating the process the basic options are either the approach of evaluation over the business unit, top-down (Horvàth, Reinhold 1989), or the evaluation based on utilisation of resources, the bottom-up approach (Schuh 1995).

\section{DESIGN OF THE FACTOR-INDICATOR MODEL}

\subsection{Definition of business units and processes}

Following examples are based on a benchmarking project conducted for the function "Inbound logistics“ of the business process "Order fulfilment" in 9 companies of Volkswagen (Gühring et al 1997, p. 282).

First step for designing the FI-model is to specify business unit(s) and, referring to the degree of investigation, the analysis of the processes. Figure 2 shows 1 out of 10 reference processes for the function of inbound logistics which were modelled by the SADT technique using IDEF0 (Mertins 1993, p. 32).

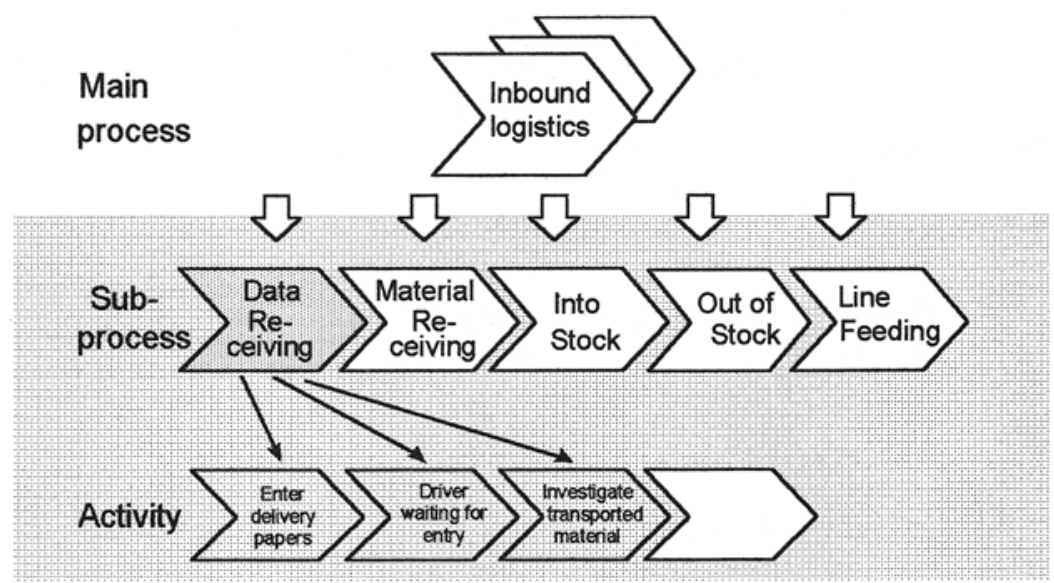

Figure 2 Reference model for a main process of inbound logistics

\subsection{Definition of performance indicators}

Next step is the definition of the indicator(s) for evaluating the process. Naturally indicators must be understandable to persons involved. Further the measures for the indicator must be defined and obtainable. In the project a productivity indicator was used calculated by the comparison of employees to a standardised box volume (DREHER 1997, p. 168) which was handled by these employees. Evaluation 
was carried out for departments and for processes running through the departments. Allocation of resources to the processes was based on the box volume of the individual process (Gühring et al 1997, p. 285).

\subsection{Definition of success factors}

Third step is the definition of success factors: By collecting many influencing factors and reducing them to the success factors, the current performance is explained and possible improvement activities may be derived. When implementing the technical improvement (or maybe just only) soft factors also have to be considered. In Figure 4 the specification of success factors was carried out with the software tool GAMMA (1994), showing only the active factors.
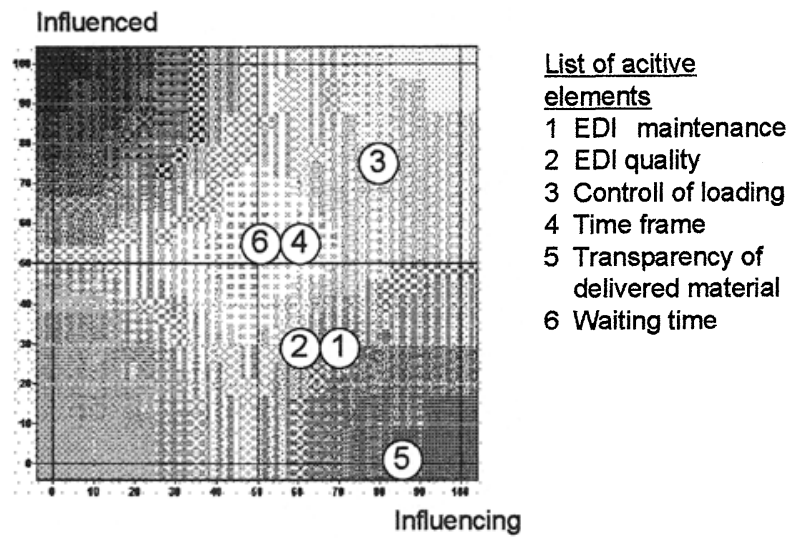

6 Waiting time

Figure 4 Success factors for sub-processes „Material Receiving“

\subsection{Design of the Factor-Indicator-Model}

After reducing the elements of the system model to only relevant information, the Factor-Indicator-Model is designed to summarise the success factors, the modelled process and the performance indicator. Figure 5 shows an example. 


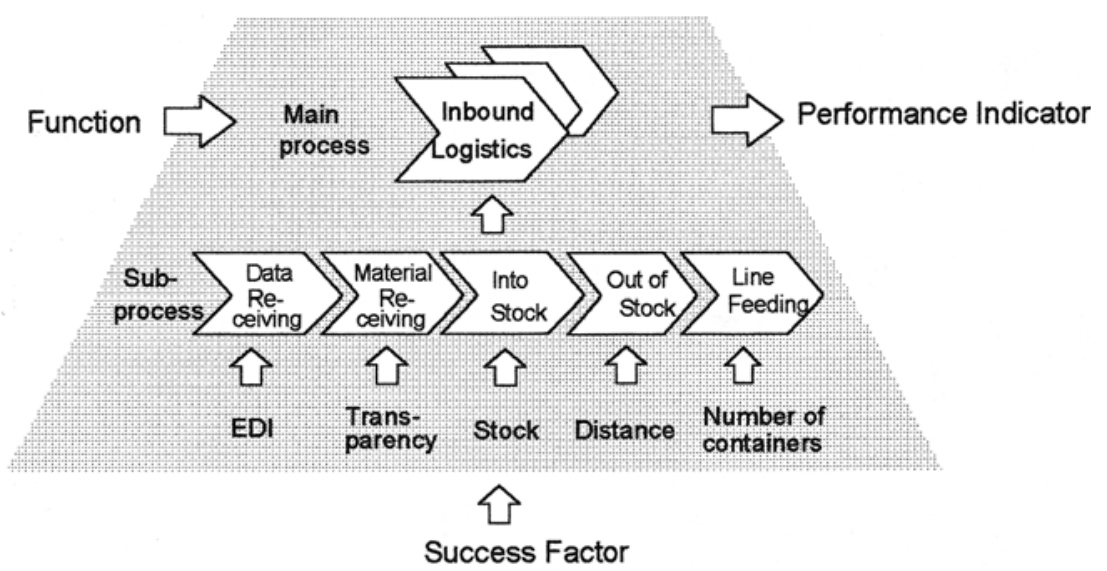

Figure 5 Factor-Indicator model of an inbound logistics process

Considering the underlying resources, Figure 6 explains performance differences based on the process of inbound logistics. This form, separated into 3 sections, provides a quick but clear view on the key figures of the investigated business unit or process. Furthermore the performance may be compared to other business units or processes, also visualised by a profile in the form.

\begin{tabular}{|c|c|c|c|c|c|c|}
\hline \multirow{2}{*}{\multicolumn{2}{|c|}{ Process: Inbound Logistics }} & \multirow{3}{*}{$\begin{array}{l}\square \text { Plant } 1 \\
* \quad \text { Plant } 2\end{array}$} & \multicolumn{4}{|c|}{ Range } \\
\hline & & & 1 & 23 & 45 & Value \\
\hline \multirow{3}{*}{ Indicator } & Productivit & & & & $\square$ & {$[40 ; 90]$} \\
\hline & Costs/SB & & & & * & {$[110 ; 138]$} \\
\hline & Leadtime/s & & ! & & & {$[3 ; 10]$} \\
\hline \multirow{3}{*}{ Resources } & Personal & & & & 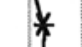 & {$[30 ; 120]$} \\
\hline & Equipment & & & & & {$[30 ; 40]$} \\
\hline & DV-system & & & & 号 & {$[90 ; 230]$} \\
\hline \multirow{4}{*}{$\begin{array}{l}\text { Success- } \\
\text { factor }\end{array}$} & EDI Applic & & & & 口 & {$[30 ; 95]$} \\
\hline & Amount of & & & & & {$[120 ; 150]$} \\
\hline & Frequency & /ery & & & 因 & {$[1 ; 10]$} \\
\hline & Packaging & & & & 因 & {$[15 ; 40]$} \\
\hline
\end{tabular}

Figure 6 Factor-Indicator-Analysis

For initiating the improvement, the "how-it-should-be-done“ is described by (the) success factor(s). The coherent indicator gives evidence for best performance. Figure 7 shows an example of a Material-Supply-Unit (MSU) coming from the underlying project, characterised by using similar parts in very 
large containers, resulting of course in a very high productivity. Besides technical success factors the consideration of soft factors needs to be considered in order to stabiles technical improvement activities.

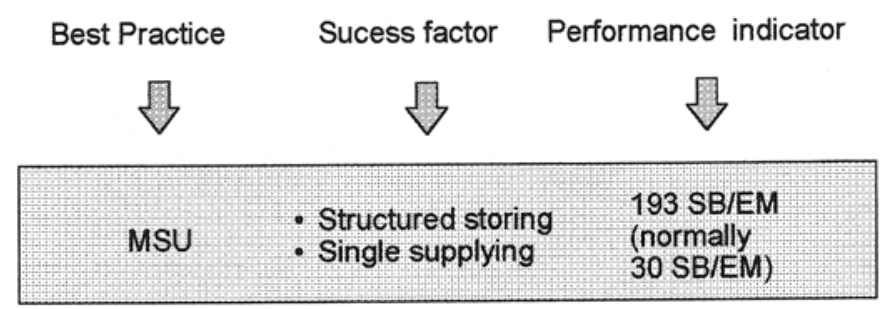

SB: Standard Box

EM: Employee

Figure 7 Presentation of a Best Practice

\section{CONCLUSIONS}

In a Factor-Indicator-Model fields as the controlling of processes by measurements and the definition of improvement activities are combined. Derived from the success factors improvement activities are specified including requirements of the employees finally running the reinforced process in operation. Applying the model success factors are defined, improvement efforts are allocated to business units or processes and performance is quantified by an indicator.

\section{REFERENCES}

Buzzle, Robert D. and Gale, Bradley T. (1989) Das PIMS-Programm. Wiesbaden. Bradley, P. and Jordan, P. (1996) An agreed business model identified a set of generic business processes. ENAPS (ESPRIT 20888). Deliverable F3-2.

Dreher, D. (1997) Logistik-Benchmarking in der Automobilindustrie. Dissertation. Wirtschafts- und Sozialwissenschaftliche. Universität Augsburg.

Eiff v. W. (1991) Die Rolle des Organisators im Prozeß der strategischen Unternehmensentwicklung, in Organisation - Erfolgsfaktor der Unternehmensführung (ed. Eiff v. W. H.). Landsberg/Lech, pp. 105-143.

Gamma Version 2.0: Portfolioanalyse für MS-Windows 3.11. Software. Unicon Management Systeme GmbH 1994.

Gühring et al (1997) Benchmarking of Inbound Logistics - Pilot studies at Volkswagen in Proceedings of SOLE Conference 97. Jerusalem, pp. 282-287.

Hopfenbeck, Waldemar (1997) Allgemeine Betriebswirtschaft- und Managementlehre. 11. Auflage, Landsberg/Lech.

Horvàth, P. and Mayer, R.(1989) Prozeßkostenrechnung - Der neue Weg zu mehr Kostentransparenz in Kostenrechnungspraxis. No. 4, pp. 214-219. 
Horvàth, P. (1995) Schnittstellenüberwindung durch das Controlling, in Synergien durch Schnittstellencontrolling (ed. Horvàth, P.). Stuttgart, pp. 123.

Lama, Joachim (1995) Prozessbenchmarking: Dargestellt an Unternehmen der Antriebstechnik. Mühlen.

Mertins, K. et al (1993) Integrierte Unternehmensmodellierung, Alphabet KG Berlin, Wien.

Schuderer, P. (1996) Prozeßorientierte Analyse und Rekonstruktion logistischer Systeme. Dissertation. Wiesbaden.

Schuh, G. (1995) Kostenmanagement in Entwicklung und Produktion mit der ressourcenorientierten Prozeßkostenrechnung in Prozeßkostenrechnung. (ed. Männel, W.) Wiesbaden, pp. 369-383.

Staehle, W. H. (1989) Management, 4. Auflage, München.

Ulrich, H. (1970) Das Unternehmen als produktives soziales System, 2. Auflage, Bern, Stuttgart.

Ulrich, H. and Probst, G. J. B. (1988) Anleitung zum ganzheitlichen Denken und Handeln. Bern, Stuttgart.

\section{BIOGRAPHY}

Prof. Franz. J. Heeg, born 1950, graduated as Engineer, Chemist and Economist. Finishing his Phd at the Institute of Work Science at RWTH Aachen in 1984, he stayed at the Institute as executive engineer. As managerial employee in the field of personel development and organisation he worked for Leypold AG in Hanau from 1987 to 1989. Before becoming Professor for Work Science at the University of Bremen in 1992, he stayed as consultant in Düsseldorf and Köln. Since 1995 he is director of BIBA, the Bremen Institute of Industrial Technology and Applied Work Science at the University of Bremen.

Tilman Gühring, born in 1965, finished an apprenticeship as mechanics at Trumpf GmbH\& Co in 1989 and graduated as Industrial Engineering from University of Karlsruhe in 1995. Since then he is at BIBA in the department of Logistics and Globally Distributed Production focusing on the European Benchmarking project ENAPS as well as on industry projects for optimising logistic processes as at VW or Daimler Benz. Since 1995 he is also employed at University of Bremen for writing lectures in the field of factory planning. 